\title{
The Moderating Effect of Board Diversity on the Relationship between Executive Committee Characteristics and Firm Performance in Oman: Empirical Study
}

\author{
Ebrahim Mohammed Al-Matari ${ }^{1}$, Abdullah Kaid Al-Swidi ${ }^{1} \&$ Faudziah Hanim Bt Fadzil ${ }^{1}$ \\ ${ }^{1}$ Faculty of Business and Economics, Ammran University, Yemen and Othman Yeop Abdullah Graduate School \\ of Business, University Utara Malaysia, Malaysia \\ Correspondence: Ebrahim Mohammed Al-Matari, Faculty of Business and Economics, Ammran University, \\ Yemen and Othman Yeop Abdullah Graduate School of Business, University Utara Malaysia, Malaysia. E-mail: \\ ibrahim_matri@yahoo.com
}

Received: February 20, 2014

Accepted: April 29, 2014 Online Published: May 26, 2014

doi:10.5539/ass.v10n12p6

URL: http://dx.doi.org/10.5539/ass.v10n12p6

\begin{abstract}
This study focuses to achieve an important objective by examining the moderating effect of board diversity (foreign member on the executive committee and executive committee commitment) on the relationship between executive committee characteristics and firm performance in Omani companies excluding those categorized under the financial sector. The sampling covers two years, 2011 and 2012. This study used multiple regression and hierarchical multiple regression to analyze the association between independent, moderating and dependent variables. Based on the findings, a positive association between executive committee independence, executive committee meeting and firm performance is revealed although it is not significant. In the same context, the finding revealed a negative relationship between executive committee size and firm performance but not significant. Moreover, the board diversity moderated the relationship between executive committee characteristics and firm performance but the effect is not significant. Finally, this study offers recommendations for future researchers at the end.
\end{abstract}

Keywords: corporate governance, executive committee characteristics, board diversity performance and Oman

\section{Introduction}

In the present time, the companies' performance is the first priority for investors in terms of evaluation throughout the globe, as the world has become a single business marketplace. Globalization has facilitated business activities and superior performance reduced the barriers that exist in corporate trade and financial investment, in a sense that businesses have now a greater opportunity to grow. Additionally, with extensive technology generation, individuals interested in performing their job tasks anywhere can look for a company that displays high performance. Therefore, company performance is the most crucial ingredient to attract people. People are who are responsible for managing firms should thus enhance firm performance by developing new plans and procedures for operations and transactions updates during the business lifecycle. With regards to significance of firm performance, the present study considers the impact of performance on the business environment in relation to some measurement like accounting-based measurement and market-based measurement as detailed in the following paragraphs.

Businesses throughout the globe require development and growth if they are to receive investments. Before investing in a particular business, investors usually make sure that the business is secured and stable financially and it has the ability to produce long-term profits (Khan, Nemati, \& Iftikhar, 2011; Mallin, 2007). Thus, investors are not attracted to companies that display negative performance and this failure to attract investment leads to negative outcome for businesses and eventually, the nation's economy.

In past years, corporate governance has increased in importance, particularly following the collapse of major corporations including Commerce Bank (1991), Arthur Anderson (2001), HIH (2001), Harris Scarfe (2001), One.Tel (2001), WorldCom (2002), Tyco (2002), Global Crossing (2002), Adelphia (2002), Lehman Brothers (2008), Freddy Mac (2008), Fanny Mae (2008), Goldman Sachs (2007), Marconi (2005), Northern Rock (2007), Parmalat and Yukos in the U.S., Europe and other continents (Jackling \& Johl, 2009; Obiyo \& Lenee, 2011; Ii, 
Kankpang, \& Okonkwo, 2012).

Similarly, in the context of the Sultanate of Oman, the country has also suffered corporate troubles that influenced large Omani companies including National Rice Mills (SADGI) and Omani National Investment Company Holding (SAOG) along with several small companies that had to request government assistance. In fact, charges have been made over the years indicating that companies keep their adverse information under wraps with regards to their ineffective internal controls and to negligent, incompetent and largely ignorant boards of directors. Some instances of fraud have been claimed against directors. In other words, mismanagement and ineffective board of directors are the reasons behind the decline of share prices that happened in 1998 and the eventual loss of investor confidence. These underscore the requirement for superior standards of corporate governance (Dry, 2003).

Corporate governance literature in both developing and developed markets reveal that the roles of a regulatory authority, board, management, suppliers, customers and creditors are critical in enhancing the firm value. In the same way, Tricker (1994) described corporate governance as an umbrella term covering particular issues from interactions between senior management, shareholders, board of directors and other firm stakeholders. This is also consistent with Claudiu and Catalin's (2007) statement that CG has a key role in improving market confidence of the company and resulting in the company's prosperity and stability.

Related to agency problems, corporate governance is a concept that is based on agency theory that is expected to serve as a tool to give confidence to investors that they will receive a return on the funds they have invested. Corporate governance is also related to how an investor can control or monitor the managers. Generally, management will seek to minimize agency cost, because higher costs would reduce the compensation offered to them (Herly \& Sisnuhadi, 2011). Therefore, agency theory postulates that CG is a mechanism that minimizes conflicts through the monitoring of management performance and making sure that management's goals are aligned with that of other stakeholders (Brickley, Coles, \& Terry, 1994).

Moreover, Imam and Malik (2007) and Khan et al. (2011) claimed that the requirement for corporate governance stems out from the possible conflicts of interest among stakeholders making the corporate structure-conflicts that are often attributed to two reasons; first, various participants have various goals and preferences and second, participants own asymmetric information of each other's actions, knowledge and preferences.

Effective corporate governance concentrates on the shareholders' interests and plays a key role in developing capital markets by safeguarding these interests (Abdurrouf, 2011). Obviously, good corporate governance practices are increasingly essential in determining the cost of capital in a capitalist market.

Additionally, corporate governance is a crucial ingredient of the firm performance and the development of the country's economy (Brava, Jiangb, Partnoyc, \& Thomasd, 2006; Ibrahim et al., 2010). Theoretically, good corporate governance should be linked to high corporate valuation. Several studies showed that investors are more inclined to a pay a premium that averages at $10-12 \%$ for effective corporate governance (Khanchel, 2007).

In the same vein, perfect corporate governance can strengthen intra-company control and can reduce opportunistic behaviours and lower the asymmetry of information, so it positively affects the high quality information disclosure (Li \& Qi, 2008). Furthermore, consistent with Magdi and Nadereh (2002), corporate governance ensures that business is being run properly and investors are recipients of a fair return.

\section{Corporate Governance and Firm Performance}

Earlier studies that examined the relationship between corporate governance and firm performance included Berle and Means (1932), Fama and Jensen (1983), Jensen and Meckling (1976), Shleifer and Vishny (1997) and Smith (1776). They found the importance of the separation between ownership and management in improving firm performance and providing confidence to shareholders. Generally, they suggest that the separation between ownership and management will give managers freedom to make the right decision at the time. It offers motivations for managers to maintain firms' effects in a manner that positively affects wealth of shareholder and improve health shareholder as well.

Literature dedicated to corporate governance sheds some light on various mechanisms that are available to shareholders to make sure that managers' actions are aligned with shareholders' interests. These are categorized into internal mechanisms with the former including board of directors, board independence and audit committee while the latter including CEO, independent member and others. Nevertheless, majority of studies concerning corporate governance primarily focuses on specific elements of governance such as board directors, board composition, audit committee, CEO duality and others. Additional to the above, most studies investigated the association between corporate governance and firm performance directly without moderators and mediators. 
Corporate governance has always had to depend on internal monitors to achieve an alignment between management and shareholders goals (Pissaris et al., 2010). Similarly, Cremers and Nair (2005) stated that corporate governance may be internal and it plays a key role in improving the firm value and performance.

Moreover, internal governance a mechanism is employed by shareholders to guarantee that their goals are aligned with that of management's (Walsh \& Seward, 1990). Therefore, internal mechanisms depend on effective structure of the board, suitable CEO compensation packages, and concentrated ownership to facilitate active monitoring (Pissaris et al., 2010). Practically, two significant forms of governance system have been developed for huge corporations in economic and financial literature namely, the Anglo-American type (outsider system) and the Japanese-German type (insider system).

Although the application of corporate governance code have been done for a long time in the developed countries and many studies have been done in their context, the results are still conflicting and unconfirmed, with various recommendations. In this scenario, it is easy to imagine the situation in underdeveloped countries, which is still suffering from how the separation of management and ownership, and where there is a great need to study the relationship between governance and performance. This justifies the goal of the current study which is to study the relationship between corporate governance and firm performance in firms of one of the developing countries (Al-Matari et al., 2012).

Based on the above explanation, this study attempts to achieve many objectives; first, to investigate the relationship between executive committee characteristics and performance. Second, this study examines the moderating effect of board diversity on the association between executive committee characteristics and one proxy of firm performance (ROA). Third, this study attempts to fill the gap in the existing literature in the developing countries that examined this relation. This study makes use of multiple regression and hierarchical multiple regression to analyses to explore the relationship between the considered independent, moderating and dependent variables. These variables are discussed in detail in the following sub-sections.

\section{Literature Review and Hypotheses Development}

\subsection{The Executive Committee Characteristics and Firm Performance}

Due to the global financial crisis of recent times that toppled many of the global commercial entities, a very big lesson can be learned by business entities that have been affected and implemented appropriate strategies for risk management. Therefore, risk management has become one of the most important elements in the context of what the company is doing to generate revenue and maximize shareholder value while maintaining the economic stability of the country in which they operate in (Al-Rashidi, 2010).

Moreover, corporate governance has begun to consider the concept of risk management in a more serious light. In consistence to the risk-based approach, a board employing firm-wide risk management system increases the risk awareness of the firm which in turn, increases firm knowledge which enables the board to reach meaningful decisions and to create a positive effect on the governance structures and the firm's control environment. Effective CG has also been evolving from merely command-and-control statements to a more continuous and proactive process identifying, measuring and managing risks across firm departments (Al-Rimawi, 2001).

The significance of risk management has been gradually increasing over the years and has showed exponential heights following the new Basel Capital Accord, the US Sarbanes Oxley Act, the European Sarbanes Oxley (8th Company Law Directive, E-SOX), the Japanese Sarbanes Oxley (Financial Instruments and Exchange Law, J-SOX), the European Union's financial Services Action Plan (FSAP) including MiFID (Markets in financial services directive, along with other Acts, Directives and Regulations).

Additionally, an oversight role should be exercised by the executive committee and evidence to that effect should be provided. The committee members should have a direct access to management's regular reports. The committee must be comprised of at least three members with majority of the members being non-executive directors and one being a member of the audit committee. Moreover, at least one of the committee members must be a risk expert and the chairman of the committee must be a non-executive director (Omani code, 2002).

Consistent to Al-Matari et al. (2012) and Yatim's (2010), this factor should be taken into consideration. The executive committee is one of the essential factors of internal corporate governance with other committees like the audit committee and ownership structure. The integrations between these committees help to improve and enhance firm's performance. In general, there is lack of literature related to the executive committee and its effect on the performance. For these reasons, the current study focuses on variables related to the executive committee characteristics namely the executive committee size, the executive committee independence and the executive committee meeting. These dimensions of the executive committee are explained in the next 
sub-section.

\subsubsection{The Executive Committee Size and Firm Performance}

The literature regarding the relationship between ECC and firm performance is very limited. Therefore, the hypothesis regarding this variable will be developed based on the literature related to board size. The first characteristic of the executive committee is the size that the executive committee size is measured by the number of members in the executive committee.

In view of the agency theory, the large number of members on the board is expected to reduce the effectiveness of the committee since they spend more time to make a decision. The big size of the board or committee spread the perspective of members (Jensen \& Meckling, 1976). In the same context, as AbdurRouf (2011) and Yermack (1996) claimed that issues of coordination, communication and decision-making hinder the performance of the company upon the increase of the number of directors. Therefore, with the inclusion of an extra member to the board, elements of diversity offset that of coordination.

From the resource dependence theory's point of view, the board is responsible to obtain firm resources on the basis of the board members' relationship with other firms (Pfeffer, 1972; Provan, 1980; Zald, 1967). The theory further suggests that the larger the size of the board, the better is the corporate governance as the board becomes a pool of various skills, knowledge and expertise. Large boards are more able to offer the diversity that would assist firms in securing critical resources and minimizing environmental uncertainties (Goodstein et al., 1994; NazliAnum, 2010; Pearce \& Zahra, 1992; Pfeffer, 1987). The extra members on the boards help the committee through the experience and knowledge contributed by them to bring about a superior decision which in turn, leads to the enhancement of the firm's performance.

Due to the lack of literature related to the relationship between executive committee size and firm performance and in the light of the agency theory and resource dependence theory, the following hypotheses are formulated:

\section{$H_{1}$ : There is a relationship between the executive committee size and $R O A$.}

\subsubsection{The Executive Committee Independence and Firm Performance}

The executive committee independence is measured by the number of independent members in the executive committee. This variable lacks the empirical evidence from literature.

The external board members are more persistent in their monitoring responsibility of the decisions of the firm as it is their responsibility to ensure that the financial performance is strong (Johnson et al., 1993; Stanwick \& Stanwick, 2010).

From the agency theory perspective, Berle and Means (1932) and Fama and Jensen (1983) expound that external boards could reinforce the firm's value by bringing experience to the board and by their monitoring services. According to the resource dependence theory, the integration of the board independence depends on the board's contribution to improve performance of a firm. And they can use their experience and knowledge to make a right decision at the right time (Pearce \& Zahra, 1992; Pfeffer, 1987).

Based on previous discussion and theoretical evidence, the following hypotheses are proposed:

$\mathrm{H}_{2}$ : There is a positive relationship between the executive committee independence and $\mathrm{ROA}$.

\subsubsection{The Executive Committee Meeting and Firm Performance}

The meeting of executive committee is a critical element in the determination of the effectiveness of the executive committee. The board's effectiveness also hinges on the frequency of meetings. Regular meetings of the board may lead to the improvement of the efficiency of the firm performance as the board has ample management monitoring and reviewing opportunities (Hsu \& Petchsakulwong, 2010). The executive committee is measured by the frequency of meetings of the executive committee in a year.

One aspect of resource dependency theory linked with CG and performance is the intensity of board activity, as measured by the frequency of board meetings. The theory postulates that board meeting helps the board to valuate and pursue board business from time to time and to solve any problem that may exist in the firm. In contrast, based on the agency theory, Jensen (1993) stated that boards have to be inactive and high activity indicates a reaction to adverse performance. Similarly, Rebeiz and Salame (2006) claimed that frequency of the meetings of the boards is not as important as the quality of the meetings. More particularly, frequent meetings indicate that the board is attempting to play an operating role inappropriately as opposed to an oversight role. This activity becomes inaccurate as the function of the board is to govern management and not to manage the firm. Therefore, the following hypotheses are postulated: 


\section{$H_{3}$ : There is a relationship between the executive committee meeting and $R O A$.}

3.2 The Moderating Effect of the Board Diversity on the Relationship between Executive Committee and Firm Performance

This study highlights significant variables that academically and practically assist policymakers to comprehend the need to improve the codes of corporate governance. It covers extensive corporate governance information needed to enhance firm performance. Majority of prior studies confined their examination to the direct relationship between CG and firm performance, which explains the similarities of most of their findings. While prior studies investigated the direct relationship, the present study is unique in a sense that it fills the literature gap through the consideration of some mediating and moderating variables. It addresses the diversification of the board, including its members' experience, qualification, foreign aspect, and its commitment and audit quality as moderating variables in the CG-firm performance relationship. This is consistent with the recommendation provided by Al-Matari et al. (2012).

The accounting scandals that happened in the recent times have led to investor concerns with corporate governance in every organization type. This is compounded by the collapse of major firms like Enron and WorldCom in the U.S., and Ansett, OneTel, and HIH in Australia that resulted in the demand of investors' and stakeholders' for effective corporate governance to strengthen the boardroom (Cheng, 2003; Houle, 1990; Park \& Shin, 2003).

Several researchers claim that diverse results create a more extensive knowledge base, where creativity and innovation becomes the competitive advantage of the firm (Erhard et al., 2003; Watson et al., 1993). Other studies that examined board structure are directed to direct relationship between board directors and firm performance. Nevertheless, the inconclusive findings between the two variables are related with the lack of studies examining moderating variables (Miller \& Triana, 2009). Accordingly, this study tries to fill the gap and offer an insight to the moderating variables.

In the perspective of the resource based theory, board diversity may be the firm's source of competitive advantage (Farrell \& Hersch, 2001; Shrader, Blackburn, \& Iles, 1997; Watson et al., 1993) as it is highly effective in pinpointing several aspects of opportunities and threats and in having an extensive range of skills and capabilities for resolving issues and bringing about decision making (Krishnan \& Park, 2005).

Hence, this study investigates the relationship between the underlying diversity factors as moderators between the relationship of board structure and firm performance in order to contribute to literature.

\subsubsection{Foreign Members Serving on the Board and Firm Performance}

The board of directors was first established to realize the right decisions. Foreign members on the board of directors refer to the proportion of foreign members to the total numbers. Foreign directors contribute invaluable knowledge to the board regarding contextual issues existing in the foreign markets, which means they contribute to the quality of strategic decision making (Zahra \& Filatotchev, 2004). They are not as likely to be related to both firm and management, which make their independence invulnerable (Van \& Ingley, 2003).

Despite the significance of this variable, a notable lack of study examining this relationship is observed. Consistent with the recommendation of Al-Matari et al. (2012) and Kang et al. (2007), the present study minimizes the gap in literature by providing a clear picture of the corporate governance-firm performance relationship. This study was contributing to literature by testing the following hypotheses.

$H_{4 a}$ : The foreign members serving in the board moderate the relationship between the size of the board directors and $R O A$.

$H_{4 b}$ : The foreign members serving in the board moderate the relationship between the board composition and ROA.

$H_{4 c}$ : The foreign members serving in the board moderate the relationship between the board meeting and ROA.

\subsubsection{The Commitment Effect of the Board and Firm Performance}

Board commitment is crucial for business evaluation. Board commitment is expected to achieve firm objectives and to solve business issues. It is measured by the attendee of the meeting (ratio of attendance of the members in a year).

Meeting attendance indicates work seriousness and assessment of problems first hand, and the resolution of problems for good decisions that will assist in achieving the entity's objectives. Similarly, regular work timeliness encourages investor's confidence in the company because commitment is a reflection of hard work 
and outstanding efforts expended to raise the company value and attract potential investors. Commitment also reflects seriousness, monitoring, evaluation, prominence, and excellence in promoting company and investor value (Al-Rimawi, 2001).

According to the agency theory, job separation facilitates independence in order to make right decisions. It brings transparency of monitoring, evaluation, and reporting to all those who are interested in the firm (Jensen \& Meckling, 1976). Board commitment reflects its members' obligation to enhance firm performance (Pfeffer \& Salancik, 1978).

In light of the importance of commitment, lack of commitment of the board, their ignorance of procedures, tasks and responsibilities is uncalled for. Similarly, Cordeiro et al. (2007), Garg (2007), Shao (2010) and Sherman (2004) called for the study of board diversity (such as board commitment)-firm performance relationship. This study therefore investigates board commitment as a moderating variable through the following hypothesis; this study was an attempt to examine the effect of relationship between the board diversity on the corporate governance and performance by testing the following hypotheses.

$H_{5 a}$ : The commitment of the board moderates the relationship between the size of the board directors and ROA.

$H_{5 b}$ : The commitment of the board moderates the relationship between the board composition and ROA.

$H_{5 c}$ : The commitment of the board moderates the relationship between the board meeting and ROA.

\section{Research Method and the Study Models}

There are 169 firms listed in the Muscat Securities Market (MSM) with the firms categorized according to their similarities. The study population comprises of non-financial firms category (http://www.msm.gov.om/). The MSM lists 81 non-financial firms on the main board and secondary board as of $20^{\text {th }}$ September, 2012. All non-financial firms (81 firms) were included by the study in the years 2011 and 2012 while all non-financial ones were excluded owing to the differences in their structure, methods and accounting practices from the former group of firms (Imam \& Malik, 2007; Mandacı \& Gumus, 2010; Maury, 2006; Schiehll \& Bellavance, 2009; Wei, 2007) and the performance companion is not straight forward (Cyril \& Sarimah, 2008). Therefore, this study aimed to investigate the hypothesis relationship in corporate unit level; therefore, the unit of analysis in this study is the Omani Public Listed Company.

The firm performance is measured by ROA that on the basis of Miller's (1995) study, ROA is the representation of a measurement that gauges the complete efficiency of how the firm's assets are used for the production of net income from the operations of the firm. He added that ROA represents the effectiveness of management in appropriating capital as they may be efficient but are unable to use capital.

This study is going to examine the relationship between executive committee characteristics namely, executive committee size (ECSIZE), executive committee independence (ECINDE), executive committee meeting (ECMEETIN) and firm performance (ROA). On the other hand, it is to explore the moderating effect of the board diversity (Foreign Member (EC_FORE) and Committee Commitment (EC_COM)) on the association between executive committee characteristics and ROA. Table 1 offers variables measurement summary.

Regarding to above relationship between independence, moderator, control variables and dependence variable that the following models will be used:

$$
\begin{aligned}
& \text { ROA }=\alpha 0+\beta 1 * \text { ECSIZE }+\beta 2 * \text { ECINDE }+\beta 3 * \text { ECMEETIN }+\beta 4 * \text { FIRMSIZE }+\beta 5^{*} \text { LEVERAG }+\varepsilon \\
& \mathbf{R O A}=\alpha 0+q 1 * \text { ECSIZE }+q 2 * \text { ECINDE }+q 3 * \text { ECMEETIN }+q 4 * \text { EC_FORE+q7EC_COM+q5*EC_FORE* } \\
& \text { ACSIZE + } 6 \text { *EC_FORE* ECINDE + १7*EC_FORE* ECMEETIN + } 28^{*} \text { EC_COM* ECSIZE + } 9 * \text { EC_COM* } \\
& \text { ECINDE }+ \text { q10*EC_COM* ECMEETIN }+ \text { q11* FIRMSIZE }+ \text { q12* LEVERAG }+\varepsilon
\end{aligned}
$$

Where:

a0-Constant

ROA: Return on Assets

ECSIZE: The Executive Committee Size

ECINDE: The Executive Committee Independence

ECMEETIN: The Executive Committee Meeting

EC_FORE: The Foreign Member on the Committee

EC_COM: The Commitment of the Committee 
F_S: Executive Committee Size * Foreign Members on the Committee

F_I: Executive Committee Independence * Foreign Members on Committee

F_M: Executive Committee Meeting * Foreign Members on Committee

C_S: Executive Committee Size * Commitment on the Committee

C_I: Executive Committee Independence * Commitment on Committee

C_M: Executive Committee Meeting * Commitment on the Committee

FIRMSIZE: Firm Size

LEVERAG: Leverage

в: Error term

Table 1. Summary of variables measurement

\begin{tabular}{|c|c|c|c|}
\hline No & VARIABLES & ACRONYM & OPERATIONALISATION \\
\hline \multicolumn{4}{|c|}{ Dependent Variables (DV) } \\
\hline 1 & Return On Assets ratio (\%) & ROA & Earnings before tax divided by total assets of the company. \\
\hline \multicolumn{4}{|c|}{ Independent Variables (IV) } \\
\hline 2 & $\begin{array}{l}\text { Executive Committee Size } \\
\text { (number) }\end{array}$ & ACSIZE & Number of members serving on the executive committee. \\
\hline 3 & $\begin{array}{l}\text { Executive Committee } \\
\text { Independence }(\%)\end{array}$ & ACINDE & Number of non-executive members serving on the executive committee. \\
\hline 4 & $\begin{array}{l}\text { Executive Committee } \\
\text { Meeting (number) }\end{array}$ & ACMEETIN & $\begin{array}{l}\text { The frequency number of meetings during a year for the executive } \\
\text { committee. }\end{array}$ \\
\hline \multicolumn{4}{|c|}{ Moderators Variables (MV) } \\
\hline 5 & $\begin{array}{l}\text { The Foreign Member on } \\
\text { the Committee (number) }\end{array}$ & EC_FORE & $\begin{array}{l}\text { The number of non-executive foreign directors divided by the total } \\
\text { number of committee members. }\end{array}$ \\
\hline 6 & $\begin{array}{l}\text { The Commitment of } \\
\text { attendance (ratio) }\end{array}$ & EC_COM & $\begin{array}{l}\text { The commitment of the committee is measured by the attendee of the } \\
\text { meeting. It meant by ratio of attendance for all the members during a } \\
\text { year. }\end{array}$ \\
\hline \multicolumn{4}{|c|}{ Control Variables (CV) } \\
\hline 7 & Firm Size (number) & FIRMSIZE & The natural log of total assets. \\
\hline 8 & Leverage $(\%)$ & LEVERAG & The ratio of total liabilities to total assets. \\
\hline
\end{tabular}

\section{Data Analysis and Results}

The gathered data is analyzed through IBM SPSS for data description and hypotheses testing.

\subsection{Descriptive Statistic}

Table 2 shows the descriptive statistics of the continuous variables. The descriptive statistics include mean, standard deviation, minimum, and maximum which were computed using SPSS version 19.

Table 2. Descriptive statistics of continuous variables

\begin{tabular}{llllll}
\hline Variables & Unit & Mean & Std. Deviation & Min & Max \\
\hline Executive Committee Size (ECSIZE) & Number & 2.14 & 1.88 & 0.00 & 6.00 \\
Executive Committee Independence (ECINDE) & Ratio & 0.54 & 0.46 & 0.00 & 1.00 \\
Executive Committee Meeting (ECMEETIN) & Number & 2.18 & 2.37 & 0.00 & 13.00 \\
Foreign Member (EC_FORE) & Ratio & 0.16 & 0.25 & 0.00 & 1.00 \\
Committee Commitment (EC_COM) & Ratio & 0.55 & 0.46 & 0.00 & 1.00 \\
FIRM SIZE (FIRMSIZE) & OR & 62979251.03 & 125657047.90 & 605320.00 & 685377000.00 \\
LEVERAGE (LEVERAG) & Ratio & 0.49 & 0.28 & 0.02 & 1.72 \\
Return On Assets (ROA) & Ratio & 0.06 & 0.10 & -0.34 & 0.32 \\
\hline
\end{tabular}




\subsection{Correlation Analysis}

A summary of the correlation results is provided in Table 8. According to the findings, the correlations are all less than 0.80, which is consistent with Gujarati and Porter's (2009) statement that the correlation matrix should remain less than 0.80 to guarantee the non-existence of the issue of multicollinearity. In addition, the study variable's tolerance values are listed in Table 4 and they range from 0.215 to 0.964 with VIF values ranging between 1.037 and 4.644, revealing that both tolerance values are higher than 0.1 and the VIF values are lower than 10 as suggested by Hair et al. (2010). In other words, the tolerance values and the VIF values are within the acceptable range, which reveals a non-existent issue of multicollinearity.

Table 3. Results of Pearson correlation analysis

\begin{tabular}{|c|c|c|c|c|c|c|c|c|}
\hline & 1 & 2 & 3 & 4 & 5 & 6 & 7 & 8 \\
\hline \multicolumn{9}{|l|}{ 1) RCSIZE } \\
\hline 2) RCINDE & $0.869^{* * *}$ & & & & & & & \\
\hline 3) RCMEETIN & $0.725 * * *$ & $0.719 * * *$ & & & & & & \\
\hline 4) EC-FORE & $0.176^{* *}$ & $0.192 * *$ & 0.033 & & & & & \\
\hline 5) $\mathrm{EC}-\mathrm{COMME}$ & $0.296^{* * *}$ & $0.285^{* * *}$ & $0.175^{*}$ & $0.482^{* * *}$ & & & & \\
\hline 6) FIRMSIZE & 0.101 & 0.037 & 0.100 & -0.096 & -0.017 & & & \\
\hline 7) LEVERAG & $-0.145^{*}$ & -0.076 & -0.122 & $0.179^{* * *}$ & -0.001 & -0.062 & & \\
\hline 8) ROA & 0.123 & 0.083 & $0.145^{*}$ & -0.061 & 0.030 & $0.257 * * *$ & $-0.451 * * *$ & \\
\hline
\end{tabular}

Notes: $* * *$ Correlation is significant at the 0.01 level (2-tailed).

$* *$ Correlation is significant at the 0.05 level (2-tailed).

* Correlation is significant at the 0.1 level (2-tailed).

\subsection{Multiple Liner Regression Analysis}

The present study employed the multiple regression analysis to establish the association between independent variables and the dependent variable and to determine the relationship direction. It presents the degree to which a set of variables has the capability of predicting a certain outcome. It is described as a multivariate statistical method employed to examine the relationship among variables. Initially, data was examined to satisfy the assumptions prior to multiple regression analysis to establish the outcome's reliability. The main assumptions examined include linearity, normality, homoscedasticity, and independence of error terms. Multicollinearity and outliers were dealt with prior to assumptions testing.

Table 4. Multicollinearity test (model 3)

\begin{tabular}{lll}
\hline Variables & Tolerance Value & VIF \\
\hline Executive Committee Size (ECSIZE) & 0.215 & 4.644 \\
Executive Committee Independence (ECINDE) & 0.222 & 4.498 \\
Executive Committee Meeting (ECMEETIN) & 0.430 & 2.323 \\
Foreign Member (EC_FORE) & 0.711 & 1.407 \\
Committee Commitment (EC_COM) & 0.718 & 1.393 \\
FIRM SIZE (FIRMSIZE) & 0.964 & 1.037 \\
LEVERAGE (LEVERAG) & 0.926 & 1.080 \\
\hline
\end{tabular}

\subsubsection{Regression Results of Model (Based on Accounting Measure)}

The $\mathrm{R}^{2}$ informs us that the percentage of variance in the independent variable (ROA) is explained by the model's variables, which are the executive committee size, independence and meeting. The results in Table 5 presents that the $\mathrm{R}^{2}$ in this model is 0.262 . This shows that the model explains $24 \%$ of the firm performance (ROA) variance, which is quite a respectable percentage. The SPSS shows an Adjusted $\mathrm{R}^{2}$ value in the output. For a small sample, $\mathrm{R}^{2}$ value in the sample tends to lean more to an optimistic overestimation of the actual population 
value (Tabachnic \& Fidell, 2007). Based on the adjusted coefficient of determination $\left(R^{2}\right), 0.238 \%$ of the variation in the dependent variable is explained by the independent variables' variations. In other words, firm performance variation, as proxied by ROA, was statistically explained by the regression equation. Moreover, the results listed in Table 5 shows that the model is significant as $F$ value is significant at $(F=10.991, p<0.01)$. This indicates the model's validity.

Moreover, this study employed the Durbin-Watson (DW) for the detection of auto-correlation. In this context, Reinard (2006) and Kazmier (1996) contended that the value of the test statistics can differ from 0 to 4.0. The rule of thumb states that Dubin-Watson values should fall in the range of 1.5-2.5. The autocorrelation test results are provided in Table 6.10, where the Durbin-Watson value is 1.892 which falls in the threshold of 1.5-2.5, indicating independence of observations.

Table 5. Regression results of model 1 (Dependent= ROA)

\begin{tabular}{|c|c|c|c|}
\hline Variables & $\begin{array}{l}\text { Standardized Coefficients } \\
\text { Beta }\end{array}$ & t-value & Sig. \\
\hline Executive Committee Size (ECSIZE) & -0.029 & -0.194 & 0.846 \\
\hline Executive Committee Independence (ECINDE) & 0.003 & 0.023 & 0.981 \\
\hline Executive Committee Meeting (ECMEETIN) & 0.090 & 0.865 & 0.388 \\
\hline FIRM SIZE (FIRMSIZE) & 0.224 & 3.194 & 0.002 \\
\hline LEVERAGE (LEVERAG) & -0.430 & -6.127 & 0.000 \\
\hline $\mathrm{R} 2$ & & & 0.262 \\
\hline Adjusted R2 & & & 0.238 \\
\hline F-value & & & 10.991 \\
\hline F-Significant & & & 0.000 \\
\hline Durbin Watson statistics & & & 1.892 \\
\hline
\end{tabular}

\subsubsection{Hierarchical Multiple Linear Regression Results}

This sub-section deals with the moderating effect of board diversity (foreign member and board commitment) on the board of directors' characteristics-firm performance relationship. The result of this relationship answers the twelfth question of the study, i.e. Does board diversity (namely foreign member and board commitment of the board) moderate the effect of the board of directors (the board size, the board independence and the board meeting) on firm performance (ROA) of companies listed in Oman? This study chose board diversity (foreign board member and board commitment) as moderating variables to contribute new knowledge to literature. Accordingly, the moderating role of board diversity (foreign board member and board commitment) was examined on the board of director's characteristics-firm performance relationship.

As previously mentioned, board of directors contribute knowledge of contextual issues existing in foreign markets and in turn, to the quality of strategic decision making (Zahra \& Filatotchev, 2004). They are also not as likely to be related to the firm or management and hence, are independent (Van \& Ingley, 2003). Thus, from the agency theory's point of view, diversity in nationality may improve the monitoring role of the board of directors which may lead to better performance of the firm.

As for board commitment, the consistent timeliness of the work facilitates investors' confidence in the firm as commitment translates to hard work and outstanding efforts to maximize firm value and attract possible investors. It also shows seriousness, monitoring, evaluation, prominence and excellence in enhancing firm value and investors' confidence (Al-Rimawi, 2001). Based on the premise of the agency theory, the separation of positions sets independence for effective decision making and brings about effective firm monitoring, evaluation, integrity and transparency for investor's (Jensen \& Meckling, 1976). Board commitment represents its members' commitment to enhance the performance of the firm (Pfeffer \& Salancik, 1978).

The control variables were examined through steps after which the un-moderated and moderated equations were developed in that order. The $\mathrm{R}^{2}$ change statistically reveals significant moderation effect (Hair et al., 2010). Where the variable is a moderator, a post-hoc graph is created to depict the impact of the moderator in the relationship between predictor and criterion variables. The test facilitates the testing of the third study objectives to identify whether or not board diversity (foreign members in the board and board commitment) affect the board 
of directors-firm performance relationship.

Regression analysis ran on the moderating effect is discussed and presented in the proceeding sub-sections. The results of this analysis are provided in the models as explained in Table 6.

Table 6. The moderating effect of the board diversity on the relationship board directs characteristic and ROA

\begin{tabular}{|c|c|c|c|c|c|c|c|c|c|c|c|c|}
\hline \multirow[t]{2}{*}{ Variables } & \multicolumn{3}{|c|}{$\begin{array}{l}\text { Step1 } \\
\text { Control variable }\end{array}$} & \multicolumn{3}{|c|}{$\begin{array}{l}\text { Step } 2 \\
\text { Without interaction }\end{array}$} & \multicolumn{3}{|c|}{$\begin{array}{l}\text { Step3 } \\
\text { Moderator variable }\end{array}$} & \multicolumn{3}{|c|}{$\begin{array}{l}\text { Step4 } \\
\text { With interaction }\end{array}$} \\
\hline & Beta & $\mathbf{T}$ & Sig. & Beta & $\mathbf{T}$ & Sig. & Beta & $\mathbf{T}$ & Sig. & Beta & $\mathbf{T}$ & Sig. \\
\hline FIRMSIZE & 0.23 & 3.34 & 0.001 & 0.22 & 3.19 & 0.00 & 0.23 & 3.22 & 0.00 & 0.22 & 3.03 & 0.00 \\
\hline LEVERAG & -0.44 & -6.35 & 0.000 & -0.43 & -6.13 & 0.00 & -0.44 & -6.07 & 0.00 & -0.46 & -6.18 & 0.00 \\
\hline ECSIZE & & & & -0.03 & -0.19 & 0.85 & -0.04 & -0.27 & 0.79 & -0.05 & -0.31 & 0.75 \\
\hline ECINDE & & & & 0.00 & 0.02 & 0.98 & -0.01 & -0.03 & 0.97 & -0.00 & -0.02 & 0.99 \\
\hline ECMEETIN & & & & 0.09 & 0.87 & 0.39 & 0.10 & 0.94 & 0.35 & 0.13 & 1.17 & 0.24 \\
\hline EC_FORE & & & & & & & 0.04 & 0.47 & 0.64 & 0.06 & 0.67 & 0.51 \\
\hline EC_COM & & & & & & & 0.01 & 0.13 & 0.90 & -0.01 & -0.12 & 0.92 \\
\hline ECS_FORE & & & & & & & & & & -0.10 & -0.57 & 0.58 \\
\hline ECI_FORE & & & & & & & & & & 0.08 & 0.43 & 0.67 \\
\hline ECM_FORE & & & & & & & & & & 0.08 & 0.73 & 0.47 \\
\hline ECS_COM & & & & & & & & & & -0.09 & -0.50 & 0.62 \\
\hline ECI_COM & & & & & & & & & & -0.06 & -0.28 & 0.78 \\
\hline ECM_COM & & & & & & & & & & 0.09 & 0.75 & 0.45 \\
\hline F value & 27.23 & & & 10.99 & & & 7.82 & & & 4.38 & & \\
\hline F Sig. & 0.00 & & & 0.00 & & & 0.00 & & & 0.00 & & \\
\hline $\mathrm{R} 2$ & 0.26 & & & 0.26 & & & 0.26 & & & 0.28 & & \\
\hline Adjusted R2 & 0.25 & & & 0.24 & & & 0.23 & & & 0.21 & & \\
\hline R2 change & 0.26 & & & 0.01 & & & 0.00 & & & 0.02 & & \\
\hline Significant $F$ change & 0.00 & & & 0.77 & & & 0.84 & & & 0.78 & & \\
\hline Durbin Watson & & & & & & & & & & & & 1.892 \\
\hline
\end{tabular}

Step 1: In this model, the firm size and leverage are entered as a control variable into the regression model in the first step, with coefficient of determination F-value (27.23) and F Sig (0.000). This model found (R2) to be 0.26 , indicating that $26 \%$ of the firm performance (ROA) can be explained by the firm size and leverage with Significant $F$ change of 0.000 . The result in Table 6 showed that the firm size (FIRMSIZE) was found to be positively significant with Tobin`s $\mathrm{Q}$ with the indicators $(\beta=0.23, \mathrm{t}=3.34, \mathrm{p}>0.1)$. On the other hand, Table 6 shows a negatively significant relationship between leverage and ROA with the indicators $(\beta=-0.44, t=-6.35$, $\mathrm{p}>0.1$ ).

Step 2: In this model, the three executive committee characteristics (size, independence and meeting) were introduced to the model. This model was found to be significant $(\mathrm{F}=10.99, \mathrm{p}<0.01)$ with adjusted $\mathrm{R} 2$ as 26 per cent and significant $F$ change at the 0.01 level of significance. The results in Table 6 show that he firm size (FIRMSIZE) was found to be positively significant with ROA with the indicators $(\beta=0.22, t=3.18, p>0.01)$. On the other hand, Table 6 shows a negatively significant relationship between leverage and ROA with the indicators $(\beta=-0.43, t=-6.13, p>0.01)$. Finally, executive committee size, executive committee independence and executive committee meeting were found to have insignificant effect on ROA with indicators $(\beta=-0.03, t=-0.19$, $\mathrm{p}>0.1, \beta=0.00, \mathrm{t}=0.02, \mathrm{p}>0.1, \beta=0.09, \mathrm{t}=0.87, \mathrm{p}>0.1)$ respectively.

Step 3: In this model, foreign member on the committee (AC_FORE) and board commitment (AC_COM) were introduced to examine its predictive power toward firm performance (ROA). This model was found to be significant $(\mathrm{F}=7.82, \mathrm{p}<0.01)$ with adjusted $\mathrm{R}^{2}$ of 26 per cent. Even though the model showed significance at the 0.01 level, it did not improve the explanatory power of the model since the $\mathrm{R}^{2}$ change was significant $\left(\mathrm{R}^{2}\right.$ change $=0.009, \mathrm{p}<0.01)$. Furthermore, this model accounted for 23 per cent of the variance in the model.

The results in Table 5 show that firm size was found to have a strong positive effect on firm performance (ROA) 
with the indicators $(\beta=0.213, \mathrm{t}=3.22, \mathrm{p}<0.01)$. Moreover, the leverage also found to have a strong negative effect on firm performance (ROA) with the indicators $(\beta=-0.44, t=-6.07, p<0.001)$. On the other hand, executive committee size, executive committee independence, executive committee meeting, the foreign member on the committee and the commitment of committee were found to have an insignificant relationship with ROA with the indicators $(\beta=-0.04, \mathrm{t}=-0.27, \mathrm{p}>0.05),(\beta=-0.01, \mathrm{t}=-0.03, \mathrm{p}<0.05),(\beta=0.10, \mathrm{t}=0.94, \mathrm{p}<0.05),(\beta=0.04, \mathrm{t}=$ $0.47, \mathrm{p}<0.05)$ and $(\beta=-0.01, \mathrm{t}=0.13, \mathrm{p}<0.05)$ respectively.

Step 4: In this model, the interaction terms between board diversity (foreign member on the board and board commitment) and executive committee (size, independence and meeting) were examined to test the moderating effects in this study. This model was reported to be significant at the 0.01 level of significance $(F=4.38, p<0.05)$. However, this model found to be insignificant $(\mathrm{R} 2$ change $=0.02, \mathrm{p}>0.1)$. The result in Table 5 showed that firm size was found to have a strong positive effect on firm performance (ROA) with the indicators $(\beta=0.22, t=3.03$, $\mathrm{p}<0.01)$. Otherwise, the leverage also found to have a strong negative effect on firm performance (ROA) with the indicators $(\beta=-0.46, \mathrm{t}=-6.18, \mathrm{p}<0.001)$. An insignificant relationship were revealed between executive committee size, executive committee independence, executive committee meeting, foreign member on committee and the commitment committee to ROA with the indicators $(\beta=-0.05, \mathrm{t}=-0.31, \mathrm{p}<0.05),(\beta=-0.00, \mathrm{t}=$ $-0.02, \mathrm{p}<0.05),(\beta=0.13, \mathrm{t}=1.17, \mathrm{p}<0.05),(\beta=0.06, \mathrm{t}=0.67, \mathrm{p}<0.05)$ and $(\beta=-0.01, \mathrm{t}=-0.12, \mathrm{p}<0.05)$ respectively. The results regarding the interaction terms reveals that the model was insignificantly moderated by board diversity at all on the association between executive committee characteristics and ROA.

Furthermore, the Durbin-Watson (DW) test is often used for detecting correlation. According to Reinard (2006) and Kazmier (1996), the value of the test statistics may differ from 0 to 4.0 and based on the rule of thumb, the Durbin-Watson should fall in the range of 1.5-2.5. Consistent with the rule of thumb, the Durbin-Watson (DW) values was found to be 1.829 indicating the non-existence of any issue.

\section{Discussion of Results}

This study highlights all outcomes of the examination of the association between executive committee characteristics and firm performance (ROA) as well as present the result of the moderating effect of board diversity on the association between executive characteristics and ROA. First of all, this study found a negative relationship between executive committee size and ROA but it is not significant. The insignificant results of committee size shows that Oman is characterized as a developing country with developing capital market and it also show that external corporate governance mechanism is still weak. The scenario is such that participants of the capital market consider independent boards to be more significant than the board's size or the strength of the executive committee. Owing to ineffective governance mechanisms, board independence, as reflected by independent commissioners and leadership structure, is opted for in the capital market in Oman. Moreover, this study found a positive but insignificant association between executive committee independence and ROA. A reason for the insignificant result between executive committee independence and ROA is the novelty of committee in Omani firms and the lack of attention paid to it. It is imperative that the Omani capital market should update its Code of Corporate Governance in order to stay abreast with international changes. The Omani Security Commission (OSC) should also mandate listed companies to adhere to policy to improve performance. In addition, this study found a positive relationship between executive committee meeting and ROA, but it is not significant. The presence of an insignificant relationship revealed between the frequency of executive committee meetings and ROA may be attributed to inefficient board meetings as the short time NEDs spent in meetings is spent in other trivial matters as opposed to exchange of useful ideas. This is because meetings are often directed by the chief executive officers. Moreover, the frequency of executive committee meetings variable has not been made mandatory to all listed companies, which explains the downplaying of its significance.

On the contrary, this study found opposite results to the ones hypothesized, as it reveals no moderating effect of board diversity on the relationship between executive committee characteristics and firm performance. The insignificant moderating effect of foreign members in the committee on the executive committee characteristics (size and meeting)-ROA relationship cab be explained by the fact that foreign members may be unaware of the current environment and how to use the limited information they in their decision making. This may also be explained to the company's mistrust of foreign members and hence, its secrecy of pertinent information from them. Thus, the Omani Security Commission (OSC) should identify the conditions of foreign members and their work involvement, and their rights and duties to enhance firm's performance. For instance, to date, foreign members are not recipients of materials and moral incentives that could encourage them to work seriously to achieve company goals.

Additionally, the results revealed insignificant moderate effect of the committee's commitment on the executive 
characteristics (size, independence, and meetings)-ROA relationship. This may be explained by the inefficient board sizes which almost always fail to efficiently do their work as they are under qualified and experienced, and unable to deal with the current environment. This may also be explained by the statement provided by Rebeiz and Salame (2006). They contended that frequency of board meetings is secondary to board meetings quality and it is usually acknowledged that the higher the board meetings frequency, the more likely the board is managing the company as opposed to playing its actual oversight role.

\section{Conclusion}

As proved above, this study achieved various objectives with the main one being to examine the moderating relationship in an emerging country, specifically Oman. Secondly, it is the first study to highlight the association between executive committee characteristics and firm performance. Third, it aimed to explore the moderating effect of board diversity on the association between executive committee characteristics and firm performance. Lastly, it is an attempt to bridge the gap in the existing literature dedicated to examining the relationship between corporate governance and firm performance both in the developed countries and in the developing countries.

This study covered non-financial companies in two years, 2011 and 2012. The multiple regression and hierarchical multiple regression analyses were used to examine the relationship between executive committee characteristics, moderating effect of board diversity on the corporate governed and firm performance with firm performance as the dependent variable. Moreover, this study used two control variables namely firm size and leverage. This study's findings were unfortunately opposite to the predicted hypotheses. It found relationships between all executive committee characteristics and firm performance, but they were not significant. Similarly, this study failed to support the hypothesis of moderating effect of board diversity on the association between executive committee characteristics and ROA as explained by various reasons in the previous section.

Ultimately, this study like prior studies, offers some recommendations-first, this study recommends future researchers to replicate the same in other Gulf countries. Second, this study suggests future authors to investigate others variables besides the variables already investigated, for instance, board of director characteristics, ownership structure, audit committee characteristics, risk committee characteristics, compensation committee characteristics, external corporate governance mechanisms and others, which facilitate enhancement of firm performance and provide a clear picture of all mechanisms that may help policy makers to improve the code of corporate governance. Third, this study is the pioneering study to explore the moderating effect of board diversity on the relationship between committee characteristics and firm performance although the variables considered are few. So, it recommends future to add some variables to board diversity such as experience, qualification, age, religion, sex and others that may lead to the enhancement of firm performance. Fourth, due to the inconclusive results of the relationship between corporate governance and firm performance, the present study recommends ones to examine this relation through moderator and mediator variables such audit quality, compensation and others. Fifth, this study suggests future authors to extend the sampling to financial sectors, and the duration of study from two years.

\section{References}

Abdurrouf, M. A. (2011). The relationship between corporate governance and value of the firm in developing countries: Evidence from Bangladesh. The International Journal of Applied Economics and Finance, 5(3), 237-244.

Al-Matari, E. M., Al-Swidi, A. K., Faudziah, H. B., \& Al-Matari, Y. A. (2012). The Impact of board characteristics on Firm Performance: Evidence from Nonfinancial Listed Companies in Kuwaiti Stock Exchange. International Journal of Accounting and Financial Reporting, 2(2), 310-332. http://dx.doi.org/10.5296/ijafr.v2i2.2384

Al-Matari, Y. A., Al-Swidi, A. K., \& Fadzil, F. H. B. (2012). Audit committee effectiveness and performance of Saudi Arabia listed companies. Wulfenia Journal, 19(8), 169-188.

Al-Matari, Y. A., Al-Swidi, A. K., Fadzil, F. H. B., \& Al-Matari, E. M. (2012). Board of directors, audit committee characteristics and performance of Saudi Arabia listed companies. International Review of Management and Marketing, 2(4), 241-251.

Al-Rimawi, L. M. (2001). Jordanian, Kuwaiti and Omani Securities Regulation: Can they be Subject Matter of a Viable Comparative Study with EU Securities Regulation? (Part Two). Journal of Financial Regulation and Compliance, 9(3), 253-273. http://dx.doi.org/10.1108/eb025080

Berle, A., \& Means, G. (1932). The Modern Corporation and Private Property. New York, NY: Macmillan. 
Brava, A., Jiangb, W., Partnoyc, F., \& Thomasd, R. (2006). Hedge fund activism, corporate governance, and firm performance. Working paper, 1-54.

Brickley, J. A., Coles, J. L., \& Terry, R. L. (1994). Outside directors and the adoption of poison pills. Journal of Financial Economics, 35, 371-390. http://dx.doi.org/10.1016/0304-405X(94)90038-8

Cheng, S. (2003). Time to revamp insider boards, national real estate investor, 45, 72.

Claudiu, B., \& Catalin, M. B. (2007). Corporate governance and firm performance. Management and Marketing Journal, University of Craiova, Faculty of Economics and Business Administration, 5(1), 125-131.

Cordeiro, J. J., Veliyath, R., \& Romal, J. B. (2007). Moderators of the relationship between director stock-based compensation and firm performance. Corporate Governance, 15(6), 1384-1394. http://dx.doi.org/10.1111/j.1467-8683.2007.00652.x

Cremers, K. J. M., \& Nair, V. B. (2005). Governance mechanisms and equity prices. Journal of the finance, 5(6), 2859-2894. http://dx.doi.org/10.1111/j.1540-6261.2005.00819.x

Cyril, H. P., \& Sarimah, R. (2008). Governance and performance: Publicly listed companies in Malaysia. Journal of Business Systems, Governance and Ethics, 3(1), 35-53.

Dry, E. K. (2003). Corporate governance in the Sultanate of Oman, 1(3), 45-82.

Erhardt, N. L., Werbel, J. D., \& Shrader, C. B. (2003). Board of director diversity and firm financial performance. Corporate Governance: An International Review, 11(2), 102-111. http://dx.doi.org/10.1111/1467-8683.00011

Fama, E. F., \& Jensen, M. C. (1983). Separation of ownership and control. Journal of Law and Economics, 26, 301-325. http://dx.doi.org/10.1086/467037

Fama, E., \& Jensen, M. (1983). Agency problems and residual claims. The Journal of Law and Economics, 26(2), 327-349. http://dx.doi.org/10.1086/467038

Farrell, K. A., \& Hersch, P. L. (2001). Additions to corporate boards: Does gender matter? SSRN, 28, 1-30.

Garg, A. K. (2007). Influence of board size and independence on firm performance: A study of Indian companies. VIKALPA, 32(3), 39-61.

Goodstein, J., Gautam, K., \& Boeker, W. (1994). The effects of board size and diversity on strategic change. Strategic Management Journal, 15, 241-250. http://dx.doi.org/10.1002/smj.4250150305

Gujarati, D., \& Porter, D. (2009). Basic Econometrics (5th ed.). New York: McGraw-Hill.

GulfBase. (2013). GCC Stock Markets-Markets Summary. Retrieved from http://www.gulfbase.com/

Hair, J. F., Anderson, R. E., Tatham, R. L., \& Black, W. C. (2010). Multivariate data analysis (2nd ed.). New York: Prentice-Hall, Upper Saddle River, NJ.

Herly, M., \& Sisnuhadi. (2011). Corporate governance and firm performance in Indonesia. International Journal of Governance, 1(1), 1-20.

Houle, C. O. (1990). Who should be on your Board? Nonprofit World, 8, 33-35.

Hsu, W., \& Petchsakulwong, P. (2010). The impact of corporate governance on the efficiency performance of the Thai non-life insurance industry. The Geneva Papers on Risk and Insurance Issues and Practice, 35(1), S28-S49. http://dx.doi.org/10.1057/gpp.2010.30

Ibrahim, Q., Rehman, R., \& Raoof, A. (2010). Role of corporate governance in firm performance: A comparative study between Chemical and Pharmaceutical sectors of Pakistan. International Research Journal of Finance and Economics, 50, 7-16.

Imam, M. O., \& Malik, M. (2007). Firm performance and corporate governance through ownership structure: Evidence from Bangladesh Stock Market. International Review of Business Research Papers, 3(4), 88-110.

Jackling, B., \& Johl, S. (2009). Board structure and firm performance: Evidence from India's top companies. $\begin{array}{llll}\text { Corporate } \quad \text { Governance: An International } & \text { Review, }\end{array}$ http://dx.doi.org/10.1111/j.1467-8683.2009.00760.x

Jensen, M. (1993). The modern industrial revolution, exit and the failure of internal control systems. Journal of Finance, 48, 831-880. http://dx.doi.org/10.1111/j.1540-6261.1993.tb04022.x

Jensen, M., \& Meckling, W. H. (1976). Theory of the firm: Managerial behavior, agency costs, and ownership 
structure. Journal of Financial Economics, 3, 305-360. http://dx.doi.org/10.1016/0304-405X(76)90026-X

Johnson, R. A., Hoskisson, R. E., \& Hitt, M. A. (1993). Board of director involvement in restructuring: The effects of board versus managerial controls and characteristics. Strategic Management Journal, 14, 33-50. http://dx.doi.org/10.1002/smj.4250140905

Kazmier, L. (1996). Schaum's Outline of Theory and Problems of Business Statistics. McGraw-Hill, 1996-Business and Economics-410 pages.

Khan, K., Nemati, A. R., \& Iftikhar, M. (2011). Impact of corporate governance on firm performance evidence from the Tobacco industry of Pakistan. International Research Journal of Finance and Economics, 61, $7-14$.

Khanchel, I. (2007). Corporate governance: Measurement and determinant analysis. Managerial Auditing Journal, 22(8), 740-760. http://dx.doi.org/10.1108/02686900710819625

Krishnan, H. A., \& Park, D. (2005). A few good women-on top management teams. Journal Business Research, 58, 1712-1720. http://dx.doi.org/10.1016/j.jbusres.2004.09.003

Li, H., \& Qi, A. (2008). Impact of corporate governance on voluntary disclosure in Chinese listed companies. Corporate Ownership Control, 5, 360-366.

Ll, J., Kankpang, K., \& Okonkwo, G. (2012). Corporate governance as a driver of organizational efficiency in courier service firms: Empirical findings from Nigeria. Interdisciplinary Journal of Research in Business, $1(1), 26-38$.

Magdi, \& Nadereh. (2002). Corporate governance practice and performance. New York, Dave Publishers.

Mallin, C. (2007). Corporate governance (2nd ed.). Oxford: Oxford University Press.

Mandac1, P. E., \& Gumus, G. K. (2010). Ownership concentration, managerial ownership and firm performance: Evidence from Turkey. SEE Journal, 57-66.

Maury, B. (2006). Corporate performance, corporate governance and top executive turnover in Finland. European Financial Management, 12(2), 221-248. http://dx.doi.org/10.1111/j.1354-7798.2006.00317.x

Miller, D. J. (1995). CEO salary increases may be rational after all: Referents and contracts in CEO pay. Academy of Management Journal, 38, 1361-1385. http://dx.doi.org/10.2307/256861

Miller, T., \& Triana, M. (2009). Demographic diversity in the boardroom: Mediators of the board diversity-firm performance relationship. Journal of Management Studies, 46(5), 755-786. http://dx.doi.org/10.1111/j.1467-6486.2009.00839.x

NazliAnum, M. G. (2010). Ownership structure, corporate governance and corporate performance in Malaysia. International Journal of Commerce and Management, 20(2), 109-119. http://dx.doi.org/10.1108/10569211011057245

Obiyo, O. C., \& Lenee, L. T. (2011). Corporate governance and firm performance in Nigeria. IJEMR, 1(4), 1-12.

Park, Y. W., \& Shin, H. H. (2003). Board composition and earnings management in Canada. Journal of Corporate Finance, 185, 1-27.

Pearce, J. H., \& Zahra, S. A. (1992). Board composition from a strategic contingency perspective. Journal of Management Studies, 29(2), 411-438. http://dx.doi.org/10.1111/j.1467-6486.1992.tb00672.x

Pfeffer, J. (1987). A resource dependence perspective on inter-organizational relations. In M. S. Mizruchi, \& M. Schwartz (Eds.), Inter-corporate relations: The structural analysis of business (pp. 22-55). Cambridge, UK: Cambridge University Press.

Pfeffer, J., \& Salancik, G. (1978). The external control of organizations: A resource dependence perspective. New York: Harper and Row.

Pfeffer, J., \& Slanick, G. R. (1979). The external control of organizations: A resource dependence perspective. Contemporary Sociology, 8(4), 612-613. http://dx.doi.org/10.2307/2065200

Pissaris, S., Jeffus, W., \& Gleason, K. C. (2010). The joint impact of executive pay disparity and corporate governance on corporate performance. Journal of Managerial Issues, 22(3), 306-329.

Provan, J. (1980). Board power and organizational effectiveness among human service agencies. Academy of Management Journal, 23(2), 221-236. http://dx.doi.org/10.2307/255428

Rebeiz, K. S., \& Salameh, Z. (2006). Relationship between governance structure and financial performance in 
construction. Journal of Management in Engineering, 22(1), 20-26. http://dx.doi.org/10.1061/(ASCE)0742-597X(2006)22:1(20)

Reinard, J. (2006). Communication research statistics (pp. 600). Thousand Oaks, CA: Sage.

Schiehll, E., \& Bellavance, F. (2009). Boards of directors, CEO ownership, and the use of non-financial performance measures in the CEO bonus plan. Corporate Governance: An International Review, 17(1), 90-106. http://dx.doi.org/10.1111/j.1467-8683.2008.00723.x

Shao, G. (2010). The effects of board structure on media companies' performance: A stakeholder perspective. Journal of Media Business Studies, 7(3), 1-16.

Sherman, H. (2004). Corporate governance ratings. Corporate Governance, 12, 5-7. http://dx.doi.org/10.1111/j.1467-8683.2004.00337.x

Shleifer, A., \& Vishny, R. W. (1997). A survey of corporate governance. Journal of Finance, 52(2), 737-783. http://dx.doi.org/10.1111/j.1540-6261.1997.tb04820.x

Shrader, C., Blackburn, V., \& Iles, P. (1997). Women in management and firm financial performance: An explanatory study. Journal of Managerial Issues, 9, 355-372.

Smith, A. (1776). An Inquiry into the nature and causes of the wealth of nations. The clarendon press, Oxford.

Stanwick, P. A., \& Stanwick, S. (2010). The relationship between corporate governance and financial performance: An empirical study of Canadian firms. The Business Review, 16(2), 35-42.

Tabachnick, B., \& Fidell, L. (2007). Using Multivariate Statistics.

Tricker, R. I. (1994). International Corporate Governance: Text readings and Cases. Singapore: Prentice-Hall.

Van, D. W., \& Ingley. (2003). Board dynamics and the influence of professional background, gender and ethnic diversity of directors. Corporate Governance, an International Review, 11(3), 218-234.

Walsh, J. P., \& Seward, J. K. (1990). On the efficiency of internal and external corporate control mechanisms. Academy of Management Review, 15(3), 421-458.

Watson, E., Kumar, K., \& Michaelsen, L. (1993). Cultural diversity's impact on interaction process and performance: Comparing homogeneous and diverse task groups. Academy of Management Journal, 36, 590-603. http://dx.doi.org/10.2307/256593

Wei, G. (2007). Ownership structure, corporate governance and company performance in China. Asia Pacific Business Review, 13(4), 519-545. http://dx.doi.org/10.1080/13602380701300130

Yatim, P. (2010). Board structures and the establishment of a risk management committee by Malaysian listed firms. Journal of Management and Governance, 14(1), 17-36. http://dx.doi.org/10.1007/s10997-009-9089-6

Yermack, D. (1996). Higher market valuation of companies with a small board of directors. Journal of Financial Economics, 40(2), 185-221. http://dx.doi.org/10.1016/0304-405X(95)00844-5

Zahra, S., \& Filatotchev, I. (2004). Governance of the entrepreneurial threshold firm: A knowledge-based perspective. Journal of Management $\quad$ Studies, $\quad 41, \quad 885-897$. http://dx.doi.org/10.1111/j.1467-6486.2004.00458.x

Zald, M. N. (1967). Urban differentiation, characteristics of board of directors, and organizational effectiveness. American Journal of Sociology, 73, 261-272. http://dx.doi.org/10.1086/224474

\section{Copyrights}

Copyright for this article is retained by the author(s), with first publication rights granted to the journal.

This is an open-access article distributed under the terms and conditions of the Creative Commons Attribution license (http://creativecommons.org/licenses/by/3.0/). 